Wstęp: Chore leczone operacyjnie z powodu raka szyjki macicy i raka endometrium w przypadku stwierdzenia niekorzystnych czynników prognostycznych wymagają leczenia uzupełniającego przy użyciu technik radioterapii. Każdemu leczeniu promieniami mogą towarzyszyć odczyny, zarówno wczesne, jak i późne.

Materiat i metody: Analizą objęto 173 chore otrzymujace uzupełniajacca radioterapię po leczeniu operacyjnym z powodu raka szyjki macicy (38 chorych) i raka endometrium (135 chorych). Wszystkie chore zostały poddane teleterapii i brachyterapii. W całej grupie oceniono odczyny popromienne wczesne i późne.

Wyniki: Stwierdzono, że pacjentki chore na raka endometrium były starsze niż chore na raka szyjki macicy $(p<0,002)$. Odczyny wczesne wystąpiły u 48,5\% chorych, odczyny późne u 9,8\% chorych. Zaobserwowano, że zarówno odczyny wczesne, jak i późne występowały częściej ze strony układu pokarmowego aniżeli układu moczowego (26\% i 22,5\% - wczesne, oraz 8,1\% i 1,73\% - późne). Wyższy odsetek odczynów związanych $\mathrm{z}$ radioterapią odnotowano $\mathrm{w}$ grupie chorych na raka szyjki macicy niż na raka endometrium $(60,5 \%$ i $37,7 \%)$. Odczyny popromienne późne przeważały również w grupie chorych na raka szyjki macicy (13,2\% i 8,9\%). Wystąpienie odczynów popromiennych $w$ trakcie leczenia wiązało się z zastosowaniem przerw w radioterapii. Pacjentki chore na raka endometrium częściej miały przerwy w napromienianiu niż pacjentki chore na raka szyjki macicy $(7,4 \%$ i $2,6 \%$ ). Autorzy zauważyli, że odczyny popromienne wczesne występowały zdecydowanie częściej niż odczyny popromienne późne. Częściej stwierdzono odczyny - zarówno wczesne, jak i późne - u chorych na raka szyjki macicy niż raka endometrium. Przerwy w napromienianiu dłuższe niż 7 dni występowały częściej u chorych na raka endometrium niż raka szyjki macicy, co prowadziło do wydłużenia całkowitego czasu leczenia.

Słowa kluczowe: radioterapia uzupełniająca, rak endometrium, rak szyjki macicy, odczyn wczesny, odczyn późny.

\section{Analysis of acute and late toxicity of adjuvant radiotherapy in women with cervical and endometrial cancer}

\author{
Ocena odczynów popromiennych wczesnych i późnych \\ w radioterapii uzupetniającej $u$ chorych na raka endometrium \\ i raka szyjki macicy
}

\section{Żaneta Wareńczak-Florczak, Andrzej Roszak, Hanna Włodarczyk, Arleta Wojciechowska-Łącka}

Wielkopolskie Centrum Onkologii w Poznaniu

\section{Wstęp}

Chore leczone operacyjnie zarówno z powodu raka szyjki macicy, jak i raka endometrium w przypadku stwierdzenia niekorzystnych czynników prognostycznych w ocenie histopatologicznej materiału pooperacyjnego wymagają leczenia uzupełniającego przy użyciu technik radioterapii. Polega ona na łaczeniu teleradioterapii konformalnej, obejmujacej napromienianiem miednice mniejsza, i brachyterapii dopochwowej, której celem jest podwyższenie dawki promieniowania w szczycie pochwy. Napromienianie miednicy mniejszej, w tym narządów zdrowych (jelit i pęcherza moczowego), wiąże się z występowaniem wczesnych (do 90 dni od zakończenia leczenia) i późnych odczynów popromiennych. Ich obecność oraz nasilenie mogą być związane z wpływem wielu czynników, takich jak: wysokość dawki promieniowania (z teleterapii i brachyterapii), wysokość dawki frakcyjnej, rozkład dawki w narządach zdrowych, wiek i stan ogólny leczonych chorych, w tym występowanie poważnych schorzeń internistycznych (cukrzycy, zaburzeń układu krążenia, otyłości). Decyzja o zakwalifikowaniu chorych do radioterapii uzupełniającej powinna uwzględniać zarówno pozytywne efekty napromieniania, jak i możliwość wystąpienia powikłań. Dlatego analiza obecności odczynów popromiennych jest ważną częścią oceny leczenia skojarzonego u tych chorych.

Celem pracy była analiza wczesnych oraz późnych odczynów popromiennych w grupie chorych otrzymujących radioterapię uzupełniającą.

\section{Materiat i metody}

Charakterystyka pacjentek i leczenia

Analizą objęto 173 chore otrzymujące uzupełniającą radioterapię po leczeniu operacyjnym z powodu raka szyjki macicy (RSzM) w stopniach IB-IIA wg FIGO (38 chorych) i raka endometrium (RE) w stopniach I-IIIA wg FIGO (135 chorych). Kwalifikacja do radioterapii uzupełniającej wynikała z wystąpienia u tych chorych niekorzystnych czynników prognostycznych.

Teleradioterapię konformalną prowadzono przy użyciu czterech wiązek skrzyżowanych z zastosowaniem osłon z kolimatora wielolistkowego; u 15 chorych zastosowano technikę IMRT (inter modulate radiation therapy). Objętość napromieniania obejmowała lożę po usuniętym narządzie rodnym wraz ze spływem chłonnym miednicy mniejszej. Dawka frakcyjna wynosiła 1,8 Gy podawana 5 razy w tygodniu. Dawka całkowita w obszarze napromieniania (planning target volume) wynosiła średnio 43,4 Gy/T \pm 5 Gy. 
Background: In case of pure prognostic factors women with cervical and endometrial cancer after surgical operation need to be treated with radiotherapy. Every radiation treatment may be involved with toxicity, acute and late. Material and methods: Performed was detailed analysis of 173 patients with cervical (38) and endometrial (135) cancer. We evaluated early and late post radiation reactions in all patients.

Results: Acute reactions were found in $48.5 \%$ and late toxicity was found in $9.8 \%$ of patients. Women with endometrial cancer were significantly older then patients with cervical cancer $(p<0.002)$. Higher percentage of acute and late toxicity was observed from the bowel tah urinary tract $(26 \%$ and $22.5 \%$ acute; $8.1 \%$ and $1.73 \%$ - late). Higher percentage of acute side effects was observed in patients with cervival than with endometrial cancer $(60.5 \%$ and $33.7 \%$ ). Late post radiation reaction predominate also in patient with cervical cancer (13.2\% and $8.9 \%)$. The adverse effects were associated with prolonged time of treatment due to breaks in radiotherapy. Higher percentage of breaks was found in older patients, more frequent in patient with endometrial than in cervical cancer group (7.4\% and $2.6 \%$ ).To conclude early postradiation reaction appeared more frequently, than late post radiation reactions. It was stated that early and late post radiation reaction appear more frequently in women with cervical than in endometrial cancer. Interruption in radiation delivery was longer than seven days in group with endometrial cancer that leads to extension of complete radiation treatment.

Key words: adjuvant radiotherapy, endometrial cancer, cervical cancer, acute toxicity, late toxicity.
Wszystkie chore otrzymały wysokodawkową brachyterapię (high dose rate - HDR ) - 3 frakcje po 6,0 Gy aplikowane raz w tygodniu. Dawka została obliczona na 0,5 cm od powierzchni aplikatora o średnicy dostosowanej do anatomii pochwy pacjentki $(2,0-4,0 \mathrm{~cm})$.

\section{Metody}

Obserwacja pacjentek była prowadzona prospektywnie, w trakcie prowadzonego leczenia (oceny dokonywano raz w tygodniu) oraz w trakcie badań kontrolnych w okresie dwóch lat po zakończeniu leczenia. Analizowano wiek i stan ogólny chorych oraz występujące odczyny popromienne ze strony przewodu pokarmowego i układu moczowego. Analiza dotyczyła także przebiegu leczenia promieniami, w tym przerwy w napromienianiu. Przebieg radioterapii analizowano na podstawie dokumentacji medycznej oraz protokołu napromieniania. Do oceny odczynów popromiennych wczesnych i późnych użyto skali EORTC (tab. 1. i 2.). W dalszej analizie odczyny w stopniu 1. i 2. były oceniane wspólnie jako łagodne, a odczyny w stopniu 3. i 4. jako odczyny ciężkie.

Wyniki analizowano przy zastosowaniu skali $\chi^{2}$, Fisher-Freeman-Halton, testu U Manna-Whitneya oraz testu Fishera dwustronnego. Oceniono także korelację pomiędzy zastosowanymi skalami metodą Kappa.

\section{Wyniki}

Analiza całej grupy badanej oraz porównanie pomiędzy dwoma wyodrębnionymi podgrupami

Stwierdzono, że pacjentki chore na raka endometrium (RE) były starsze niż chore na raka szyjki macicy (RSzM) ( $p<0,002)$. Średnia wieku u chorych z rozpoznaniem RE wynosiła 64,9 $\pm 8,2$ roku, u chorych na RSzM 54,0 $\pm 8,7$.

Zarówno masa ciała, jak i wskaźnik masy ciała (body mass index - BMI) były wyższe u chorych na RE i wynosity odpowiednio: dla chorych na RE - masa 78,7 $\pm 5 \mathrm{~kg}$ oraz BMI 31,8; dla chorych na RSzM $65 \pm 6,3 \mathrm{~kg}$ oraz BMI 25,4.

Odczyny wczesne stwierdzono u 48,5\% wszystkich napromienianych (173 chorych), odczyny późne występowały u 9,8\% chorych. Stwierdzono, że zarówno odczyny wczesne, jak i późne obserwowane u chorych występowały częściej ze strony układu pokarmowego aniżeli układu moczowego (26\% układ pokarmowy i 22,5\% układ moczowy dla odczynów wczesnych oraz 8,1\% i 1,73\% dla odczynów późnych).

Wystąpienie odczynów popromiennych w trakcie leczenia wiązało się z wydłużeniem całkowitego czasu napromieniania. Wynikało to z konieczności zastosowania przerw, w tym również dłuższych niż 7 dni. Chore na RE częściej miały przerwy w napromienianiu niż pacjentki z RSzM (7,4\% i 2,6\%). Główną przyczyną wystąpienia przerw były odczyny ze strony układu pokarmowego. Zwraca uwagę, że kobiety z RE były średnio o 10 lat starsze.

\section{Ocena wczesnych odczynów popromiennych}

Wyższy odsetek odczynów związanych z radioterapią stwierdzono w grupie chorych na RSzM w porównaniu z chorymi na RE (odpowiednio u 60,5\% i $37,7 \%)$.

Analizę odczynów popromiennych ze strony układu pokarmowego i układu moczowego w tej grupie chorych przedstawiono w tabelach 3. i 4.

Liczba i nasilenie odczynów ze strony jelit u chorych w obu rozpoznaniach klinicznych była zbliżona (26,6 vs 23,7\%); przeważały odczyny łagodne, jednak w obu grupach występowały odczyny ciężkie w stopniu 3., w tym odpowiednio u 7,9\% z RSzM i 8,9\% z RE.

Analiza wykazała większe różnice w występowaniu wczesnych odczynów popromiennych w pęcherzu moczowym w badanych grupach chorych aniżeli w przypadku odczynów ze strony jelit.

Wyższy odsetek chorych zgłaszających odczyny zanotowano u chorych leczonych z powodu RSzM (36,8\%) niż RE (18,5\%). Różnica ta dotyczyła zarów- 
Tabela 1. Ostre odczyny popromienne w pęcherzu i jelitach w skali EORTC/RTOG Table 1. Acute toxicity in bladder and bowels in EORTC/RTOG scale

\begin{tabular}{|c|c|c|}
\hline Stopień & Pęcherz moczowy & Jelita \\
\hline 1. & $\begin{array}{l}\text { częstomocz, nokturia (2 razy częściej niż zwyczajowo), } \\
\text { dyzuria niewymagająca leczenia }\end{array}$ & $\begin{array}{l}\text { większa częstość oddawania stolca, } \\
\text { stolce biegunkowe niewymagające leczenia }\end{array}$ \\
\hline 2. & $\begin{array}{l}\text { częstomocz lub nokturia rzadziej niż raz na godzinę, } \\
\text { dyzuria wymagająca leczenia farmakologicznego }\end{array}$ & $\begin{array}{l}\text { biegunka lub bóle brzucha wymagające leczenia } \\
\text { farmakologicznego }\end{array}$ \\
\hline 3. & $\begin{array}{l}\text { częstomocz lub nokturia częściej niż raz na godzinę, } \\
\text { dyzuria lub bóle skurczowe wymagające leczenia }\end{array}$ & $\begin{array}{l}\text { biegunka wymagająca pozajelitowego nawadniania } \\
\text { (krew w stolcu, płaty śluzówki), bolesne „stawanie” } \\
\text { pętli jelitowych }\end{array}$ \\
\hline 4. & krwiomocz wymagający transfuzji, owrzodzenia, martwica & $\begin{array}{l}\text { ostra (lub podostra) niedrożność, przetoka, } \\
\text { perforacja jelita; krwawienie ze stolca wymagające } \\
\text { transfuzji }\end{array}$ \\
\hline
\end{tabular}

Tabela 2. Późne odczyny popromienne w pęcherzu i jelitach w skali EORTC/RTOG Table 2. Late toxicity in bladder and bowels in EORTC/RTOG scale

\begin{tabular}{|c|c|c|}
\hline Stopień & Pęcherz moczowy & Jelita \\
\hline 1. & $\begin{array}{c}\text { niewielkie zmiany atroficzne nabłonka pęcherza: } \\
\text { drobne teleangiektazje }\end{array}$ & $\begin{array}{l}\text { tendencja do biegunek, nadmierna perystaltyka, } \\
\text { zwiększona częstość oddawania stolca (poniżej } 5 \text { razy } \\
\text { na dobę); niewielka domieszka krwi lub śluzu }\end{array}$ \\
\hline 2. & $\begin{array}{c}\text { częstomocz miernego stopnia; uogólnione teleangiektazje; } \\
\text { okresowo krwiomocz }\end{array}$ & $\begin{array}{l}\text { okresowo biegunki lub bóle brzucha (spastyczne); } \\
\text { częstotliwość stolca powyżej } 5 \text { razy na dobę; } \\
\text { obfita domieszka krwi lub śluzu w stolcu }\end{array}$ \\
\hline 3. & $\begin{array}{c}\text { stały częstomocz, dyzuria; rozległe teleangiektazje, } \\
\text { często z wybroczynami; częsty krwiomocz; pojemność } \\
\text { pęcherza zmniejszona }(<150 \mathrm{ml})\end{array}$ & $\begin{array}{c}\text { zwężenie światła lub krwawienie wymagające } \\
\text { leczenia chirurgicznego }\end{array}$ \\
\hline 4. & $\begin{array}{l}\text { martwica; zwłóknienie pęcherza (pojemność < } 100 \text { ml); } \\
\text { częste krwotoczne zapalenie pęcherza; przetoka }\end{array}$ & martwica, perforacja, przetoka \\
\hline
\end{tabular}

Tabela 3. Odczyny popromienne wczesne w jelitach Table 3. Acute toxicity in bowels

\begin{tabular}{lccc}
$\begin{array}{l}\text { Rozpoznanie kliniczne } \\
\text { (liczba chorych) }\end{array}$ & \multicolumn{3}{c}{ Stopień odczynów (liczba chorych i \%) } \\
\cline { 2 - 4 } & 0 & 1. i 2. & 3. i 4. \\
RSzM (38) & $29(76,3 \%)$ & $6(15,8 \%)$ & $3(7,9 \%)$ \\
RE (135) & $99(73,3 \%)$ & $24(17,8 \%)$ & $12(8,9 \%)$
\end{tabular}

Tabela 4. Odczyny popromienne wczesne ze strony układu moczowego

Table 4. Acute toxicity in the urinary tract

\begin{tabular}{lccc|}
$\begin{array}{l}\text { Rozpoznanie kliniczne } \\
\text { (liczba chorych) }\end{array}$ & \multicolumn{3}{c}{ Stopień odczynów (liczba chorych i \%) } \\
\cline { 2 - 4 } & 0 & 1. i 2. & 3. i 4. \\
RSzM (38) & $24(63,16 \%)$ & $11(28,95 \%)$ & $3(7,89 \%)$ \\
RE (135) & $110(81,48 \%)$ & $23(17,03 \%)$ & $2(1,49 \%)$
\end{tabular}

no odczynów łagodnych, jak i ciężkich. Zwraca uwagę wysoki odsetek odczynów w stopniu 3. u chorych na RSzM.

\section{Ocena późnych odczynów popromiennych}

Stwierdzono wyższy odsetek odczynów późnych u chorych otrzymujących radioterapię z powodu RSzM aniżeli
Tabela 5. Odczyny popromienne późne w jelitach

Table 5. Late toxicity in bowels

\begin{tabular}{lccc} 
Rozpoznanie kliniczne & \multicolumn{3}{c}{ Stopień odczynów (liczba chorych i \%) } \\
\cline { 2 - 4 } (liczba chorych) & 0 & 1. i 2. & 3. i 4. \\
\hline RSzM (38) & $29(89,5 \%)$ & $6(10,5 \%)$ & $0(0 \%)$ \\
RE (135) & $99(92,6 \%)$ & $24(7,4 \%)$ & $0(0 \%)$ \\
\hline
\end{tabular}

Tabela 6. Odczyny popromienne późne w pęcherzu moczowym Table 6. Late toxicity in the urinary tract

\begin{tabular}{lccc|}
$\begin{array}{l}\text { Rozpoznanie kliniczne } \\
\text { (liczba chorych) }\end{array}$ & \multicolumn{3}{c}{ Stopień odczynów (liczba chorych i \%) } \\
\cline { 2 - 4 } & 0 & 1. i 2. & 3. i 4. \\
RSzM (38) & $24(97,4 \%)$ & $11(2,6 \%)$ & $0(0 \%)$ \\
RE (135) & $110(98,5 \%)$ & $23(1,5 \%)$ & $0(0 \%)$
\end{tabular}

u chorych na RE (odpowiednio 13,2\% i 8,9\% w każdej z grup). Może to mieć związek z nieco wyższymi dawkami promieniowania otrzymywanymi w ramach teleradioterapii przez chore na RSzM (43,9 Gy) niż RE (41,5 Gy).

Analizę odczynów popromiennych ze strony układu pokarmowego i układu moczowego w tej grupie chorych przedstawiono w tabelach 5. i 6. 
Nasilenie odczynów późnych ze strony jelit było nieco wyższe u chorych na RSzM niż RE (odpowiednio 10,53\% i 7,41\% w każdej z grup). Stwierdzono tylko odczyny w stopniu 1. i 2.

Odczyny późne ze strony pęcherza moczowego występowały wyłącznie w stopniu 1. i 2., u niewielkiego odsetka chorych (2,6\% w grupie RSzM i 1,5\% w grupie RE).

\section{Dyskusja}

Ocena tolerancji leczenia poprzez analizę częstości występowania odczynów popromiennych, zarówno wczesnych, jak i późnych, u chorych poddanych radioterapii pooperacyjnej z powodu RSzM i RE jest sprawą niezwykle istotną w powiązaniu ze wskazaniami i korzyściami z leczenia uzupełniającego w tej grupie chorych. W analizowanych grupach wczesne odczyny popromienne wystąpiły u 48,5\% chorych, natomiast odczyny późne u 9,8\%. Zwraca uwage znaczna przewaga odczynów popromiennych występujących w trakcie napromieniania i okresie do 3 miesięcy po radioterapii nad występującymi w okresie późniejszym. Wagę temu problemowi nadaje fakt, że prawie połowa napromienianych chorych zgłasza dolegliwości wynikające z zaistnienia wczesnych odczynów. Podobne wyniki, wskazujące na wyższy odsetek odczynów wczesnych niż późnych, przedstawiono w publikacjach innych autorów analizujących odczyny u chorych leczonych radioterapią uzupełniającą [1-4].

Wysoki odsetek odczynów wczesnych w grupie chorych operowanych może być związany ze zmianami w anatomii miednicy (zbliżenie odbytnicy i pęcherza moczowego do obszaru napromieniania w obrębie szczytu pochwy) w wyniku przeprowadzonego zabiegu chirurgicznego, ponadto efekty uboczne operacji, takie jak dysfunkcja pęcherza czy infekcje w obrębie dolnego odcinka układu moczowego, mogą prowadzić do nasilenia odczynów popromiennych [5-10].

Należy zwrócić uwagę, że całkowite dawki napromieniania u chorych otrzymujących uzupełniającą radioterapię są niższe aniżeli u chorych leczonych wyłącznie napromienianiem, jednakże wysokość dawki jest tylko jednym z elementów, który ma wpływ na występowanie odczynów popromiennych obok powszechnie uznanych, takich jak wiek, schorzenia metaboliczne, przewlekłe choroby układu pokarmowego czy moczowego. Łączenie teleterapii z brachyterapią dopochwową zwiększa odsetek odczynów popromiennych zarówno wczesnych, jak i późnych [7, 11-15].

Wśród 173 obserwowanych chorych stwierdzono wyższy odsetek odczynów popromiennych w obrębie układu pokarmowego aniżeli układu moczowego, zarówno w analizie odczynów wczesnych, jak i późnych. Podobne obserwacje o przewadze wczesnych i późnych odczynów ze strony układu pokarmowego opublikowano w pracach innych autorów [1-3].

Zwraca jednak uwagę duża liczba (u 38\% analizowanych kobiet) wczesnych odczynów popromiennych ze strony pęcherza moczowego u chorych na RSzM. Może to mieć związek z większym zakresem operacji u tych chorych, który różni się od wykonywanych u chorych na RE. Nasilenie obserwowanych odczynów ograniczało się jednak do stopnia 1. i 2. w skali EORTC.
Na szczególną uwagę zasługuje również duża liczba odczynów wczesnych ze strony jelit w stopniu 3. (odczynów ciężkich w stopniu 4. nie zaobserwowano) zarówno u chorych na RSzM (7,9\%), jak i RE (8,9\%). Odczyny ciężkie w trakcie radioterapii w zakresie 3-5\% obserwowało w swoich pracach wielu autorów [1, 2, 16-21]. Wydaje się, że w prezentowanej w niniejszej pracy analizie procent odczynów w stopniu 3. może mieć związek z użytą w badaniu skalą oceniającą odczyny - EORTC/RTOG. W skali tej odczyn ze strony przewodu pokarmowego jest kwalifikowany jako ciężki w stopniu 3. w przypadku konieczności nawadniania pozajelitowego. $U$ wielu chorych, zwłaszcza starszych, w przypadku nieustępującej biegunki stosowano nawodnienie dożylne, niejednokrotnie dłuższe niż 24 godz.

W badanej grupie chore na RE (135 kobiet) były istotnie statystycznie starsze aniżeli chore na RSzM $(p<0,002)$. $U$ pacjentek tych stwierdzano niejednokrotnie liczne choroby wspótistniejące: nadciśnienie, cukrzycę, astmę oraz otyłość. Obciążenie chorobami dodatkowymi i starszy wiek tych chorych powodowały, że pomimo występowania mniejszej liczby odczynów w trakcie radioterapii, stwierdzono więcej przerw w napromienianiu (> 7 dni) związanych z odczynami w porównaniu z grupą kobiet z RSzM.

Późne odczyny popromienne (> 3 miesiące od zakończenia radioterapii) wystąpiły u 13,2\% chorych na RSzM i u 8,9\% chorych na RE. Zwraca uwagę częstsze występowanie późnych odczynów ze strony układu pokarmowego (w obu grupach) [1, 3] oraz częstsze ich występowanie u kobiet leczonych z powodu RSzM. Podobne wyniki uzyskali w swoim badaniu Nori i wsp., nie odnotowano w nim odczynów późnych w stopniu ciężkim [2, 21].

Podsumowując:

1. W analizowanej grupie 173 chorych na RSzM i RE otrzymujących radioterapię pooperacyjną stwierdzono więcej wczesnych aniżeli późnych odczynów popromiennych (48,5\% i $9,8 \%)$.

2. Zaobserwowano wyższy odsetek odczynów popromiennych zarówno wczesnych, jak i późnych ze strony układu pokarmowego aniżeli układu moczowego (26\% układ pokarmowy i 22,5\% układ moczowy dla odczynów wczesnych oraz 8,1\% i 1,73\% dla odczynów późnych).

3. Stwierdzono dużą liczbę odczynów wczesnych w stopniu 3. (skala EORTC) w analizowanej grupie i to zarówno ze strony układu moczowego (7,8\% RSzM i 1,5\% RE), jak i pokarmowego (7,9\% RSzM i 8,9\%RE).

4. U chorych na RE częściej wystąpiły przerwy w napromienianiu (powyżej 7 dni) w porównaniu z chorymi na RSzM, mimo mniejszej częstości występowania odczynów związanych z napromienianiem.

\section{Piśmiennictwo}

1. Stewart KD, Martinez AA, Weiner S, et al. Ten-year outcome including patterns of failure and toxicity for adjuvant whole adominopelvic irradiation in high-risk and poor histologic feature patiens with endometrial carcinoma. Int J Radiat Oncol Biol Phys 2002; 54: 527-35.

2. Jareczek-Fossa B, Badzio A, Jassem J. Time without symptoms and toxicity (TWIST) analisis of adjuvant radiation therapy for endometrial cancer. Radiotherapy and Oncology 2004; 72: 175-81.

3. Weiss E, Hirnle P, Arnold-Bofinger H, Hess CF, Bamberg M. Therapeutic outcome and relation of acute and late side effect in the 
adjuvant radiotherapy of endometrial carcinoma stage I and II. Radiotherapy and Oncology 1999; 53: 37-44.

4. Bentzen SM, Overgard M. Relationship between early and late normal tissue injury after postmastectomy radiotherapy. Radiotherapy and Oncology 1991; 20: 159-65.

5. Jereczek-Fossa B, Bodzio A, Jassem J. Factors determining acute normal tissue reactions during postoperative radiotherapy In endometrial cancer: analysis of 317 consecutive cases. Radiotherapy and Oncology 2003; 68: 33-9.

6. Jereczek-Fossa B, Jassem J, Badzio A. Relationship between acute and late normal tissue injury after postoperative radiotherapy in endometria cancer. Int J Radiat Oncol Biol Phys 2002; 52: 476-82.

7. Jereczek-Fossa B, Jassem J, Nowak R, Badzio A. Late complications after postoperative radiotherapy in endometria cancer: analysis of 317 censecutive cases with applicatin of linear-quadratic model. Int J Radiat Oncol Biol Phys 1998; 41: 329-38.

8. Mallett V, Bump R. The epidemiology of female pelvic floor dysfunction. Curr Opinion Obestet Gynecol 1994; 6: 309-12.

9. Lanciano RM, Martz K, Montana GS, Hanks GE, et al. Influence of age, prior abdominal surgery, fraction size and dose on complication after radiation therapy for squamous cell cancer of the uterine cervix. Cancer 1992; 69: 2124-30.

10. Vervest HA, Barents JW, Haspels AA, Debruyne FM. Radical hysterectomy and function of lower urinary tract. Acta Obestet Gynecol Scand 1989; 68: 331-40.

11. Jereczek-Fossa B, Jassem J, Badzio A. Surgery followed by radiotherapy In endometria cancer: analysis of survival and patterns of failure. Int J Gynecol Cancer 1999; 9: 285-94.

12. Mayr NA, Wen B, Benda JA, et al. Postoperative radiation therapy in clinical stage I endometria cancer: corpus, cervical and lower uterine segment involvement - patterns of failure, Radiology 1995; 196: 323-8.

13. Randal ME, Wilder J, Greven K, Raben M. Role of intracavitary cuff boost after adjuvant external irradiation in early endometrial carcinoma, Int J Radiat Oncol Biol Phys 1990; 19: 49-54.

14. Stokes S, Bedwinek J, Breaux S, Kao M, Camel M, Perez CA. Treatment of stage I adenocarcinoma of the endometrium by hysterectomy and irradiation: analysis of complications, Obstet Gynecol 1985; 65: 86-92

15. Wolfson AH, Sighert SE, Markoe AM, et al. The prognostic significance of surgical staging for carcinoma of the endometrium. Gynecol Oncol 1992; 45: 142-6.

16. Algan O, Tabesh T, Hanlon WM, Hogan WM, Boente M, Lanciano $\mathrm{RM}$. Improved outcome in patients treated with postoperative radiation therapy for pathologic stagel//l endometrial cancer. Int J Radiot Oncol Biol Phys 1996; 35: 925-33.

17. Carey MS, O'Connell GJ, Johannson CR, et al. Good outcome associated with a standardized treatment protocol using selective postoperative radiation in patients with clinical stage I adenocarcinoma of the endometrium. Gynecol Oncol 1995; 57: 138-44.

18. Greven KM, Corn BW, Case D, Purser Ph, Lanciano RM. Which prognostic factors influence the outcome of patients with surgically stage endometrial cancer treated with adjuvant radiation? Int I Radiat Oncol Biol Phys 1997; 39: 413-8.

19. KuceraH, Vavra N, Weghaupt K. Benefit of external irradiation in pathologic stage I endometrial carcinoma: a prospective xlinical trial of 605 patients who received postoperative vaginal irradiation and additional pelvic irradiation in the presence of unfavorable prognostic factors. Gynecol Oncol 1990; 38: 99-104.

20. Morrow CP, Bundy BN, Kurman RJ, et al. Relationship between surgical-pathological risk factors and outcome in clinical stage I and II carcinoma of the endometrium: a Gynecologic Oncology Group Study. Gynecol Oncol 1991; 40: 55-65.

21. Fugazzi J, Han I, Lo S, Keole S, Pstel R, Zuniga C, Tekyi-Mansha S, Frazier A. Post-opertaive external beam radiotherapy and vaginal cuff brachyterapy boost for endometrial cancer: survival rates, site of failire and prognostic factors for recurrence. Radiotherapy and Oncology 2004; 23.
22. Nori D, Merimsky O, Batata M, Caputo Th. Postoperative high doserate intravaginal brachytherapy combined with external irradiation for early stage endometrial cancer: a long term follow-up. Int J Radiat Oncol Biol Phys 1994; 30: 831-7.

\section{Adres do korespondencj}

\section{lek. Żaneta Wareńczak-Florczak}

Oddział Radioterapii i Onkologii Ginekologicznej

Wielkopolskie Centrum Onkologii

ul. Garbary 15

61-866 Poznań

e-mail: zanetawarenczak@wp.pl 